\title{
Relationship between trochlear morphology and lateral patellar cartilage defect using MR Imaging
}

\section{MR görüntüleme kullanarak troklear morfoloji ve lateral patellar kartilaj defekti arasındaki iliş̧ki}

\author{
Semra Duran ${ }^{1}$, Elif Günaydın ${ }^{2}$
}

\begin{abstract}
Aim: The present study aimed to compare trochlear morphology observed on magnetic resonance imaging (MRI) between patients with lateral patellar cartilage defect and age-matched-pair control patients without cartilage defect.

Methods: A total of 75 patients with MRI-verified grade 3/4 lateral patellar cartilage defect were compared with matched-pair control patients without cartilage defects of the patellofemoral joints. Axial sequences were used to detect and evaluate patellar cartilage defects. Trochlear morphology was assessed on the basis of lateral trochlear inclination (LTI), medial trochlear inclination (MTI), sulcus angle (SA), trochlear facet asymmetry (FA), and trochlear width (TW) on axial MR images.

Results: SA was higher for both sexes in the cartilage defect group than in the control group $(\mathrm{p}<0.05)$. LTI of the cartilage defect group was significantly lower than that of the control group, particularly in females ( $p<$ 0.05). There were no significant differences in MTI between the two groups for either $\operatorname{sex}(p>0.05)$. FA for both sexes was significantly lower in the cartilage defect group than in the control group $(p<0.05)$. TW was significantly higher in the cartilage defect group than in the control group $(\mathrm{p}<0.05)$. Finally, TW of females in the cartilage defect group was significantly higher than that of females in the control group $(p<0.05)$.

Conclusion: Flattened lateral trochlea is a risk factor for structural damage to the cartilage of the latera patellofemoral joint, particularly in females.

Keywords: patellofemoral joint, chondromalacia patella, magnetic resonance imaging.
\end{abstract}

Öz

Amaç: Bu çalışmada lateral patellar kartilaj defektli hastalar ile yaş-taraf eşleştirilmesi yapılmış kartilaj lezyonu olmayan kontrol hastaları arasında manyetik rezonans görüntüleme (MRG) ile gözlenen troklear morfolojiyi karşılaştırmayı amaçladık.

Yöntem : MRG ile tanımlanan grade 3/4 lateral patellar kartilaj defektli toplam 75 hasta patellofemoral eklemde kartilaj defekti olmayan yaş-taraf eşleştirilmiş kontrol hastaları ile karşılaştırıldı. Aksiyal kesitler patellar kartilaj defektini saptamada kullanıldı. Troklear morfoloji lateral troklear inklinasyon ( LTI) , medial troklear inklinasyon ( MTI), sulkus açısı (SA), troklear faset asimetrisi (FA) ve troklear genişlik (TG) ile aksiyel kesitlerde değerlendirildi.

Bulgular : SA kontrol grubu ile karşılaştırıldığında her iki cinsiyet için defekt grubunda büyüktü $(\mathrm{p}<0.05)$. Kartilaj defekt grubunda LTI kontrol grubu ile karşılaştırıldığında , özellikle kadınlarda belirgin olmak üzere ,düşüktü $(\mathrm{p}<0.05)$. Her iki cinsiyet için her iki grup arasında MTI 'da istatistiksel olarak anlamlı fark bulunmadı $(\mathrm{p}>0.05)$. Her iki cinsiyet için kartilaj defekt grubunda FA kontrol grubu ile karşılaştırıldığında düşük idi(p < 0.05). TG kontrol grubu ile karşılaştırıldığında defekt grubunda büyüktü $(\mathrm{p}<0.05)$. Ayrıca,kartilaj defekt grubundaki kadınlarda TG kontrol grubundan büyüktü $(\mathrm{p}<0.05)$

Sonuç: Düzleşmiş lateral troklea özellikle kadınlarda lateral patellofemoral eklemde kartilajda yapısal zedelenme için risk faktörüdür.

Anahtar kelimeler : patellofemoral eklem, kondromalazik patella, magnetik rezonans görüntüleme.
${ }^{1}$ University of Health Sciences, Ankara Numune Training and Research Hospital, Department of Radiology, Ankara, Turkey.

${ }^{2}$ Ankara Medical Park Hospital, Department of Radiology, Ankara, Turkey.

\section{id}

SD: 0000-0003-0863-2443

EG: 0000-0001-7091-843X

Ethics Committee Approval: The study was approved by the local ethical authority. (Project No: 19-2648)

Etik Kurul Onayı: Calıșma lokal etik komite tarafindan onaylanmıştır. (Proje No: 19-2648)

Conflict of Interest: No conflict of interest was declared by the authors.

Çıkar Çatışması: Yazarlar çıkar çatışması bildirmemișlerdir.

Financial Disclosure: The authors declared that this study has received no financial support. Finansal Destek: Yazarlar bu çalıșma için finansal destek almadıklarını beyan etmişlerdir.

Gelis Tarihi / Received: 27.08.2019

Kabul Tarihi / Accepted: 12.02.2020

Yayın Tarihi / Published: 20.03.2020

Sorumlu yazar / Corresponding author:

Semra Duran

Adres/Address: University of Health Sciences, Ankara Numune Training and Research Hospital, Department of Radiology, Ankara, Turkey.

e-posta: semraduran91@gmail.com

Tel/Phone: +90 3124142188

Copyright (C) ACEM 


\section{Introduction}

Chondromalacia patella is the degeneration of patellar cartilage spanning a wide spectrum of severity ranging from softening and fissuration of the hyaline cartilage to bone erosion and formation of full-thickness articular cartilage defects. Although often observed in adolescents and younger adults, it is more commonly observed in older adults [1-3].

The etiology of chondromalacia patella is multifactorial, with genetic, environmental, or post-traumatic etiologies. Structural abnormalities of the patellofemoral joint may overload the patellar cartilage and subsequently result in cartilage defects [1, 4-7].

Magnetic resonance imaging (MRI) is recognized as an effective, accurate, noninvasive modality for assessing patellar cartilage defects because it offers superior soft tissue contrast, shows multiplanar capability, and allows direct visualization of articular cartilage [4, 8-10]. MRI is used to identify the stage of chondromalacia patella based on the degree of cartilage injury. Severe (grade 3 or 4 ) cartilage defects can be detected with $84 \%-87 \%$ sensitivity [8-10].

The sulcus angle (SA) and lateral trochlear inclination (LTI) are common measures of trochlear morphology [1, 3-5, 11, 12]. Several studies have investigated the association between patellar cartilage defects and trochlear morphology using MRI. However, these studies combined all patellar cartilage defects (medial, lateral, and central) into a single group. With only few studies analyzing the association between trochlear morphology and lateral patellar cartilage defects (LPCD), this association remains unclear [13-15].

Therefore, this study aimed to identify the morphological measurements of the trochlea associated with LPCD.

\section{Material and methods}

The study was approved by the local ethical committee and conducted according to the principles described in the Declaration of Helsinki. Written informed consent could not be obtained due to the retrospective design of the study.

\section{Patients}

We retrospectively reviewed 180 patients who were diagnosed with grade 3/4 LPCD on the basis of MRI evaluation between January and December 2017. The exclusion criteria were as follows: history of knee surgery or knee trauma (evidence of ligament and tendon tears or bone contusion), any diagnosis of space-occupying knee lesion, age $<35$ or $>55$ years, and MR images that were motion degraded or of insufficient quality to accurately assess joint cartilage. Finally, 75 patients with LPCD were included in this study. The control group included 75 age-matched patients with normal cartilage morphology as confirmed by MRI performed for the indication of anterior knee pain. The study was approved by the hospital's institutional review board.

\section{MRI evaluation}

All MRI examinations were performed using a 1.5-T unit (Optima; GE Medical System, Milwaukee, Wisconsin, USA), employing an extremity coil with the patient in the supine position with knee full extension. Axial fat-suppressed protondensity-weighted (PDW) (TR/TE: 2300-2800 /20-40 ms; matrix: $288 \times 224$; FOV: $18 \times 18 \mathrm{~cm} 2$; and slice thickness: 4 $\mathrm{mm})$ section images were analyzed to evaluate patellar cartilage defects and measure trochlear morphology.

LPCD was diagnosed if irregularity was noted on the cartilage surface with a loss of cartilage thickness in at least two consecutive slices. Severity of the cartilage defect was determined based on the lesion depth in accordance with the International Cartilage Repair Society Classification System [1, $4,11]$ as follows: grade 3 , loss of $>50 \%$ of the cartilage thickness without exposed bone (Figure 1a) and grade 4, full thickness cartilage loss with exposed bone (Figure 1b).
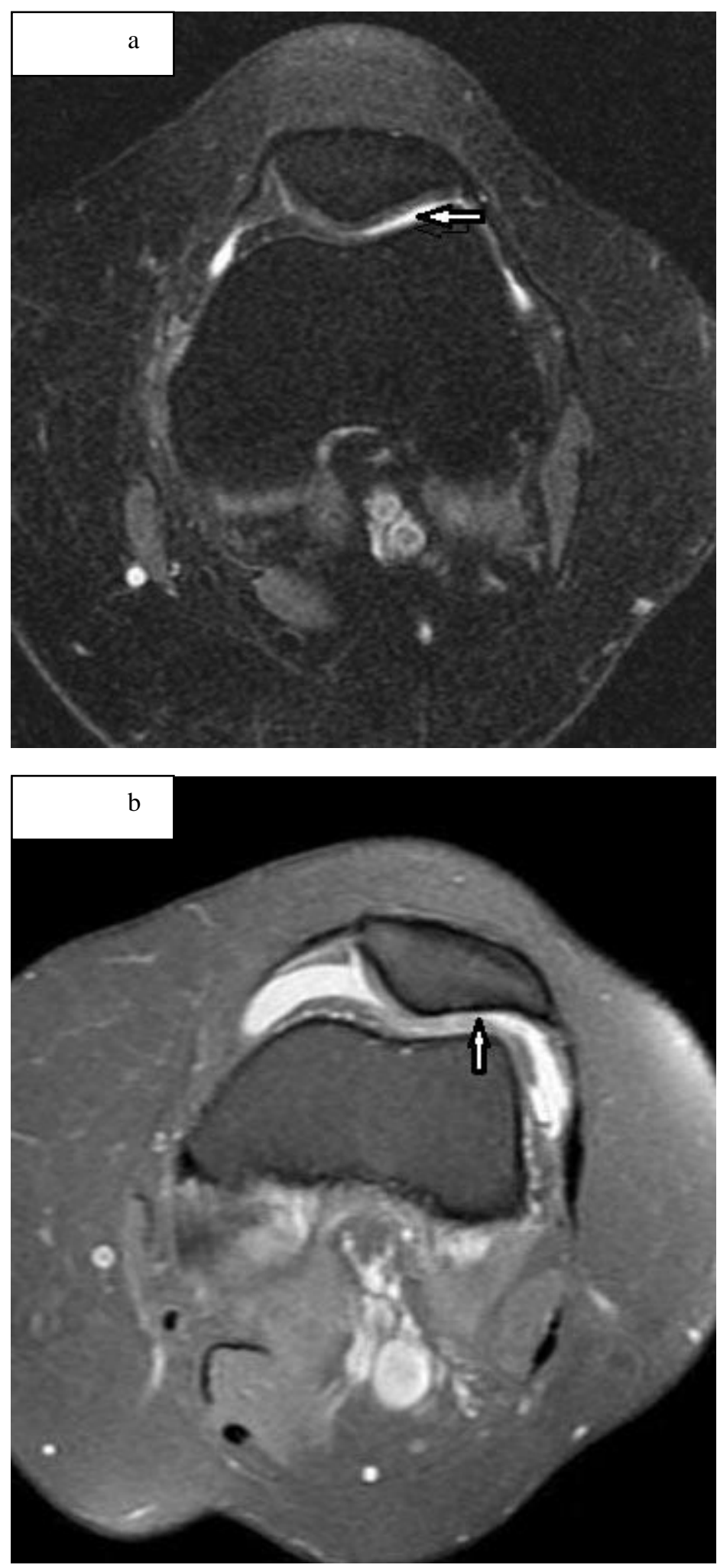

Figure 1. Axial fat-suppressed PDW-MR images of the knee showing (a) grade 3 and (b) grade 4 chondromalacia in the lateral facet of the patella (arrows).

\section{Trochlear morphology assessment}

We evaluated the morphological features of the trochlea using SA, LTI, medial trochlear inclination (MTI), trochlear facet asymmetry (FA), and trochlear width (TW). These 
measurements were taken on axial MR images, with the level of the anterior cruciate ligament femoral insertion along the osseous surface $[6,7,13]$.

SA was defined as the angle between the medial and lateral trochlear facets (Figure 2a) [1, 4, 15]. The posterior condylar line was drawn along the most posterior surface of the femoral condyles. LTI was defined as the angle between the posterior condylar line and a line drawn along the surface of the lateral trochlear facet (Figure 2b) [1, 15]. MTI was defined as the angle between the posterior condylar line and a line drawn along the surface of the medial trochlear facet (Figure 2c) [1, 15]. FA was defined by the ratio of medial facet to lateral facet length (Figure 2d) [3, 6, 7, 13]. TW was defined as the distance from the line connecting the most anterior parts of the medial and lateral femoral trochlear facets (Figure 2e) [6, 13].
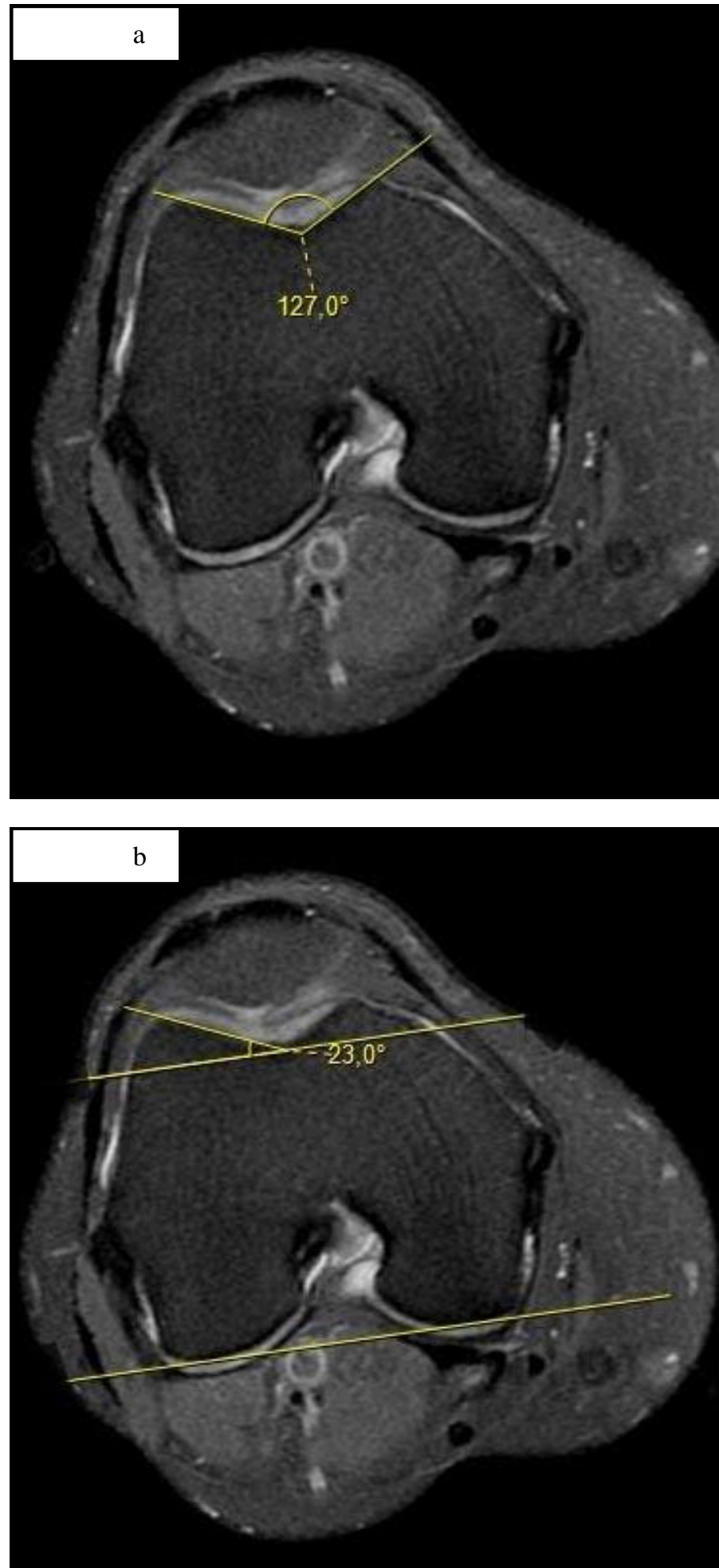
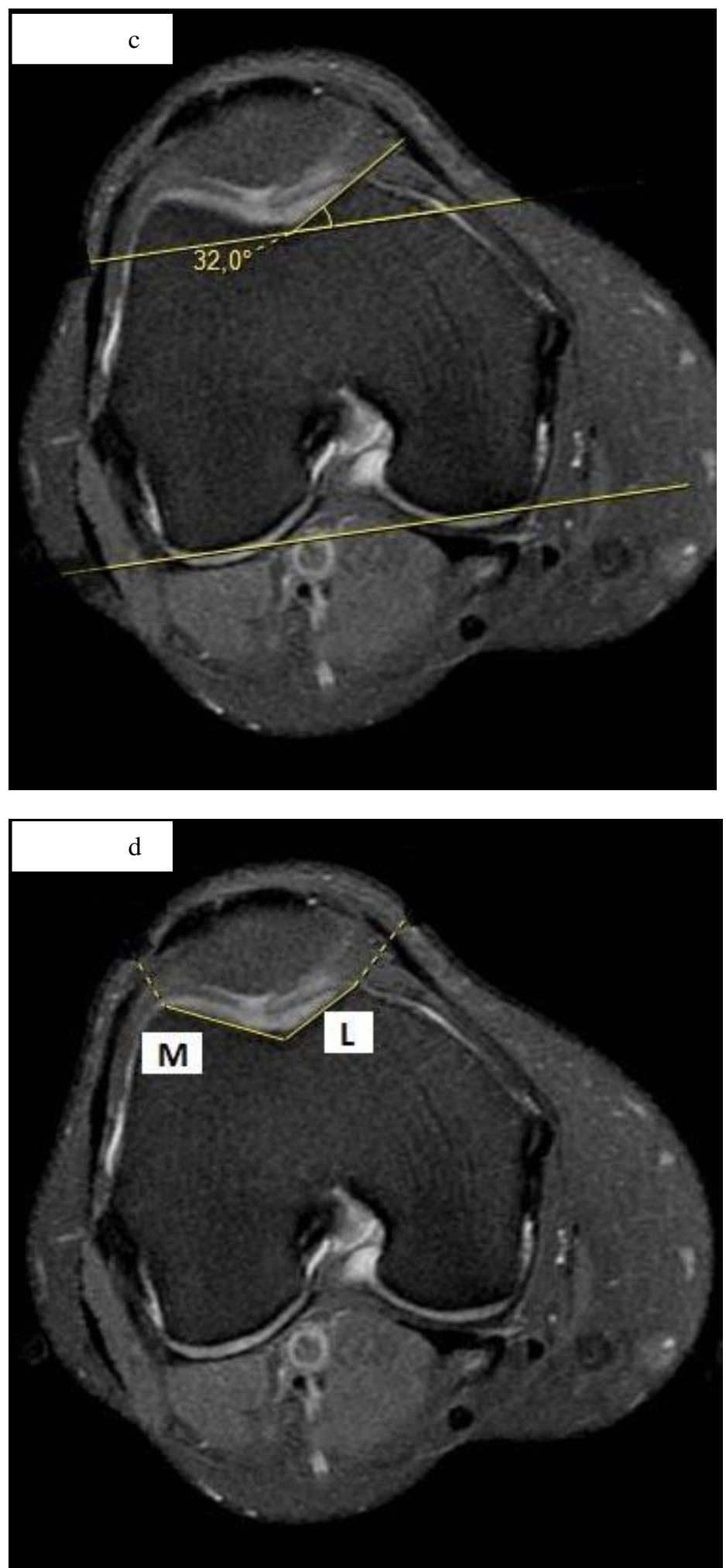

Figure 2 (a-d). Axial fat-suppressed PDW-MR images of the knee showing SA (a), LTI (b), MTI (c), and FA (d).

\section{Statistical analysis}

Statistical analyses were performed using SPSS (version 20.0; SPSS Inc., Chicago, IL). Normality of data distribution was tested using the Kolmogorov-Smirnov test. Homogeneity of data distribution was determined using Levene's test. Parametric tests were used for inter-group comparisons. Differences in SA, LTI, MTI, FA, and TW between the LPCD and control groups were analyzed using Student's t-test. Chi-square test was used to compare groups by sex. A p value of $<0.05$ was considered statistically significant. 


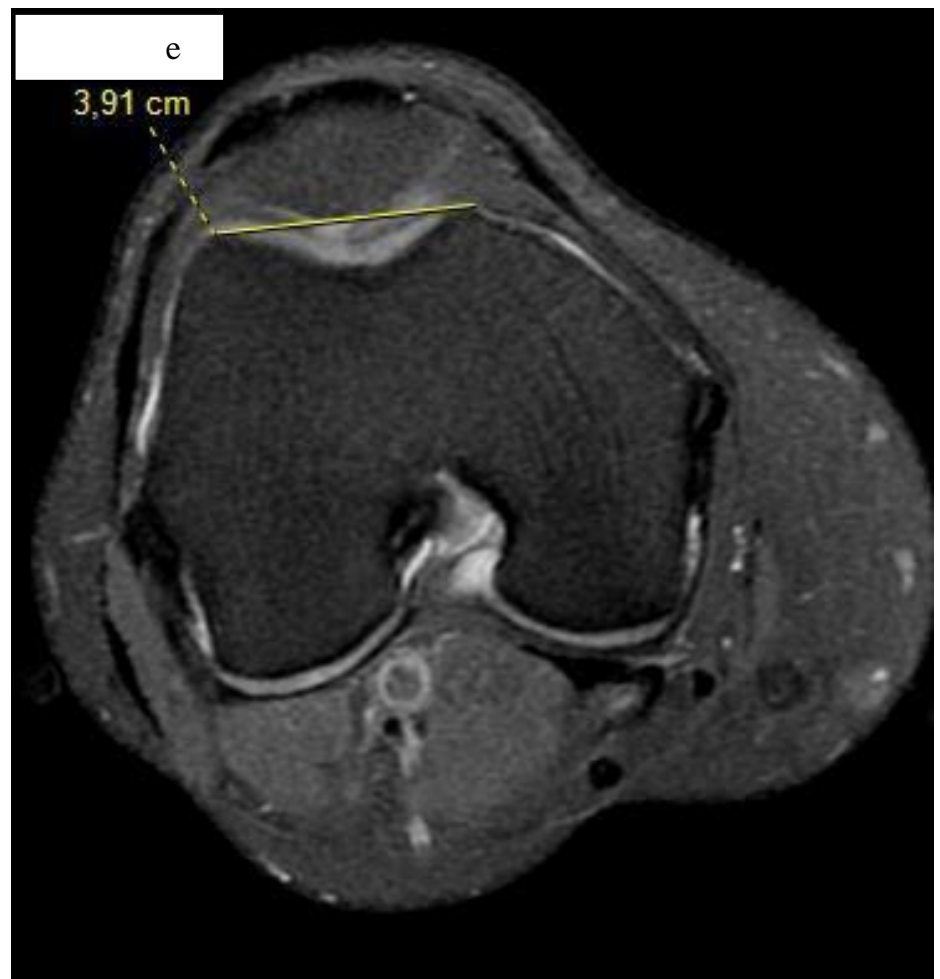

Figure 2 (continued) (e). Axial fat-suppressed PDW-MR images of the knee showing TW measurement.

\section{Reliability assessment}

All measurements of trochlear morphology were performed by one of the authors (SD). To avoid any interobserver errors in trochlear measurements, the parameters mentioned above were measured by the second author (EG) on axial images. To evaluate intraobserver reliability, measurements were performed by the same author (SD) 3 weeks after the first evaluation. Inter- and-intraobserver intraclass correlation coefficients for all measurements were 0.86 and 0.88 , respectively.

\section{Results}

The characteristics of the study participants are presented in Table 1.

Table 1. Characteristics of the study population $(n=150)$

\begin{tabular}{lcc} 
Patients & $\begin{array}{c}\text { Lateral patellar } \\
\text { cartilage defect }\end{array}$ & Control group \\
\hline Sample size & 75 & 75 \\
Age (year) (mean \pm SD) & $48.7 \pm 5.2$ & $48.1 \pm 5.4$ \\
Gender (female /male) & $50 / 25$ & $50 / 25$ \\
Right/left & $39 / 36$ & $39 / 36$ \\
\hline
\end{tabular}

SD: standard deviation.

SA for both sexes was higher in the LPCD group than in the control group $(\mathrm{p}<0.05)$. LTI of the LPCD group was significantly lower than that of the control group $(\mathrm{p}<0.05)$. Female patients in the LPCD group, but not in the control group, showed significantly lower LTI than male patients $(\mathrm{p}<0.05)$. There were no significant differences in MTI between the two groups for either sex $(p>0.05)$. FA for both sexes was significantly lower in the LPCD group than in the control group $(\mathrm{p}<0.05)$. TW was significantly higher in the LPCD group than in the control group ( $\mathrm{p}<0.05)$. TW in females was higher in the LPCD group than in the control group, whereas no such differences were noted in males $(p>0.05)$.

SA, LTI, MTI, FA, and TW comparisons between groups and sexes are summarized in Table 2.
Table 2. Descriptive analyses of trochlear parameters according to group and sex.

\begin{tabular}{llccc} 
Variable & & $\begin{array}{c}\text { Lateral patellar } \\
\text { cartilage defect } \\
(\text { mean } \pm \text { SD) }\end{array}$ & $\begin{array}{c}\text { Control group } \\
(\text { mean } \pm \text { SD })\end{array}$ & p \\
\hline SA & All & $135.1 \pm 7.7$ & $124.9 \pm 5.5$ & 0.001 \\
& Female & $136.8 \pm 7.5$ & $126.6 \pm 5.4$ & 0.001 \\
LTI & Male & $134.1 \pm 7.6$ & $124.3 \pm 5.5$ & 0.001 \\
& All & $20.2 \pm 2.6$ & $25.5 \pm 2.3$ & 0.001 \\
& Female & $15.3 \pm 2.5$ & $25.5 \pm 2.4$ & 0.001 \\
MTI & Male & $20.4 \pm 2.5$ & $25.1 \pm 2.3$ & 0.001 \\
& All & $28 \pm 2.5$ & $29 \pm 2.8$ & 0.054 \\
& Female & $27.9 \pm 2.6$ & $29.1 \pm 2.7$ & 0.055 \\
FA & Male & $27.4 \pm 2.4$ & $28.8 \pm 2.8$ & 0.055 \\
& All & $0.56 \pm 0.09$ & $0.61 \pm 0.07$ & 0.001 \\
& Female & $0.55 \pm 0.08$ & $0.60 \pm 0.08$ & 0.001 \\
TW & Male & $0.57 \pm 0.09$ & $0.61 \pm 0.08$ & 0.001 \\
& All & $36.4 \pm 4$ & $34.8 \pm 3.1$ & 0.08 \\
& Female & $35.6 \pm 3.9$ & $33.6 \pm 3.1$ & 0.08 \\
& Male & $38.5 \pm 3.9$ & $38.5 \pm 3.2$ & 0.055 \\
\hline
\end{tabular}

SD: standar deviation, SA:sulcus angle, LTI: lateral trochlear inclination, MTI: medial trochlear inclination, FA: trochlear facet asymmetry, TW: trochlear width

\section{Discussion}

This study demonstrates that abnormal trochlear morphology may play an important role in LPCD. Structural damage to the lateral patellar cartilage is commonly observed in knees with flattened lateral trochlea, particularly in females.

Patellofemoral pain syndrome is a common orthopedic problem that can cause serious disability, and it usually occurs due to chondromalasia patella. Patellar cartilage defects may develop as a result of patellofemoral morphological variations or anatomical incompatibility. Therefore, evaluation of the morphological properties of the patellofemoral joint plays an important role in the diagnosis of chondromalacia patella $[3,5$, 11, 16-19].

Several studies have suggested that patellar cartilage defects are associated with higher SA, indicative of a flattened and shallow trochlea. However, in those studies, all patellar cartilage defects (medial, lateral, and central) were grouped into a single category $[1,3-5,11,12]$. Few studies have evaluated trochlear morphology in relation to isolated LPCD [13-15]. Noehren et al. [14] reported no difference in SA between the control and LPCD groups. However, Sebro et al. [13] found that higher SA values were associated with the development of lateral patellar osteoarthrosis in young patients. Similarly, Stefanik et al. [15] found that lateral patellofemoral osteoarthritic knees with high SA are at a 1.5-fold increased risk of cartilage damage in patients aged $\geq 50$ years. In the present study, the mean SA was $135.3^{\circ}$ in the LPCD group and $124.9^{\circ}$ in the control group. These findings are in accordance with the findings of Stefanik et al. [15]. Increased SA is a risk factor for LPCD in both sexes. Shallow femoral trochlea can lead to patellar instability and disproportional load distribution on the articular surface of the patellofemoral joint during knee movement [15, 17, 19].

$\mathrm{SA}$ reflects the entire femoral trochlear morphology. In contrast, LTI reflects the lateral trochlear morphology alone. Mehl et al. [3] and Ali et al. [11] found no significant association between LTI and patellar cartilage defects in patients aged $>40$ years. However, these studies did not distinguish between medial defects and LPCD. Stefanik et al. [15] demonstrated that knees with low LTI of the lateral patellofemoral joint showed 2.6-fold increased risk of cartilage damage compared with those with high LTI. In the present study, patients with LPCD demonstrated 
significantly lower LTI than controls. In contrast to the findings of Stefanik et al. [15], we demonstrated significantly lower LTI in females than in males. Our results indicate that females with flattened lateral trochlea are at an increased risk of LPCD, which is in accordance with the findings of Duran et al [1]. When the lateral facet is flattened, the patella is more likely to be laterally displaced. Thus, the contact between the patella and lateral femoral condyle increases, leading to cartilage damage in the patellofemoral joint $[1,15,17,19,20]$.

In the present study, we did not find a significant difference in MTI between the LPCD and control groups; these findings are in agreement with those of previous studies [1, 15]. Our results suggest that the geometry of the lateral trochlear facet is more important than that of the medial trochlear facet in the structural damage of the lateral patellar cartilage.

Only few studies in the literature have analyzed the association of FA and TW with patellar cartilage defect. Mehl et al. [3] found that FA was not associated with patellar cartilage defect. However, they did not define cartilage defects in specific anatomic regions of the patellofemoral joint. Moreover, Sebro et al. [13] reported no significant association of FA and TW with lateral patellofemoral osteoarthritis in young patients. Our results suggest that with decrease in FA and increase in TW, there was an associated increase in lateral patellar cartilage structural damage in the knees of adult patients. FA for both sexes was considerably lower and TW in females significantly higher in the LPCD groups than in the control group. We suggest that the morphology of lateral trochlea is an important risk factor for LPCD.

There are some limitations in this study. It is retrospective study, and the diagnosis and grading of patellar cartilage defect were assessed based on MRI findings instead of arthroscopy. Moreover, routine MRI sequences were used for evaluation instead of cartilage-specific three-dimensional MRI for patellar cartilage.

In conclusion, our study demonstrated an association between abnormal trochlear morphology and LPCD of the knee. A flattened lateral trochlea may cause structural damage to the lateral patellar cartilage, particularly in females.

\section{References}

1. Duran S, Cavusoglu M, Kocadal O, Sakman B. Association between trochlear morphology and chondromalacia patella: an MRI study Clinical Imaging. 2017;41:7-10.

2. Berenbaum F, Eymard F, Houard X. Osteoarthritis, inflammation and obesity. Curr Opin Rheumatol. 2013 ; 25 : 114-8.

3. Mehl J, Feucht MJ, Bode G, Dovi-Akue D, Südkamp NP,Niemeyer $\mathrm{P}$.Association between patellar cartilage defects and patellofemoral geometry: a matched-pair MRI comparison of patients with and without isolated patellar cartilage defects. Knee Surg Sports Traumatol Arthrosc. $2014 ; 24: 838-46$.

4. Tuna BK, Semiz-Oysu A, Pekar B, Bukte Y, Hayırlıglu A.The association of patellofemoral joint morphology with chondromalacia patella: a quantitative MRI analysis. Clinical Imaging. 2014;38:495-8.

5. Tsavalas N, Katonis P, Karantanas AH. Knee joint anterior malalignment and patellofemoral osteoarthritis: an MRI study. Eur Radiol. 2012;22:418-28.

6. Sebro R, Weintraub S. Knee morphometric and aligment measurements with MR imaging in young adults with central cartilage lesions of the patella and trochlea. Diagn Interv Imaging. 2017;98:429-40.

7. Weintraub S, Sebro R. Superolateral hoffa's fat pad edema and trochlear sulcal angle are associated with isolated medial patellofemoral compartment osteoarthritis. Can Assoc Radiol J. 2018;69:450-7.

8. Pihlajamaki HK, Kuikka PI, Leppanen VV, Kiuru MJ, Mattila VM. Reliability of clinical findings and magnetic resonance imaging for the diagnosis of chondromalacia patellae. J Bone Joint Surg Am. 2010;92:927-34.

9. Recht MP, Piraino DW, Paletta GA, Schils JP, Belhobek GH. Accuracy of fat-suppressed three -dimensional spoiled gradientecho FLASH MR imaging in the detection of patellofemoral articular cartilage abnormalities. Radiology. 1996;198:209-12.

10. Harris JD, Brophy RH, Jia G,Price B, Knopp P,Siston RA et al. Sensivity of magnetic resonance imaging for detection patellofemoral articular cartilage defect. Arthroscopy. 2012;28:1728-37.

11. Ali SA, Helmer R, Terk MR. Analysis of the patellofemoral region on MRI: association of abnormal trochlear morphology with severe cartilage defects. AJR Am J Roentgenol. 2010;194:721-7.

12. Macri EM, Felson DT, Zhang Y, Gurmazi A, Roemer FW,Crossley KM et al. Patellofemoral morphology and aligment :refence values and dose-response patterns for the relation to MRI features of patellofemoral osteoarthritis. Osteoarthritis Cartil. 2017;25:1690-7.

13. Sebro R, Weintraub S.Association between lateral patellar osteoarthrosis and knee morphology and aligment in young adults. Clin Radiol. 2017;72:793.e11-793.e18.

14. Noehren B, Duncan S, Lattermann C. Radiographic parameters associated with lateral patella degeneration in young patients. Knee Surg Sports Traumatol Arthrosc. 2012;20:2385-90.

15. Stefanik JJ, Roemer FW, Zumwalt AC,Zhu Y, Gross KD, Lynch JA et al. Association between measures of trochlear morphology and structural features of patellofemoral joint osteoarthritis on MRI: the MOST study. J Orthop Res. 2012;30:1-8.

16. Kalichman L, Zhang Y, Niu J ,Goggins J, Gale D, Felson DT, et al .The association between patellar alignment and patellofemoral joint osteoarthritis features-an MRI study. Rheumatology (Oxford). 2007;46:1303-8.

17. Freedman BR, Sheehan FT, Lerner AL. MRI-based analysis of patellofemoral cartilage contact, thickness, and aligment in extension, and during moderate and deep flexion. Knee. 2015;22:405-10.

18. Besier TF, Garry EG, Scott LD, Fredericson M, Beaupre GS. The influence of femoral internal and external rotation on cartilage stresses within the patellofemoral joint. J Orthop Res. 2008;26:1627-35.

19. Harbaugh CM, Wilson NA, Sheehan FT. Correlating femoral shape with patellar kinematics in patients with patellofemoral pain. J Orthop Res. 2010;28:865-72.

20. Stefanik JJ, Zumwalt AC, Segal NA, Lynch JA, Powers CM. Association between measures of patella height, morphologic features of the trochlea, and patellofemoral joint alignment: the MOST study. Clin Orthop Relat Res. 2013;471:2641-8. 